\title{
CD36 Regulates Fatty Acid Composition and Sensitivity to Insulin in 3T3-L1 Adipocytes
}

\author{
K. KONTROVÁ ${ }^{1}$, J. ZÍDKOVÁ ${ }^{1,4}$, B. BARTOŠ ${ }^{1}$, V. SKOP ${ }^{1}$, J. SAJDOK ${ }^{1}$,

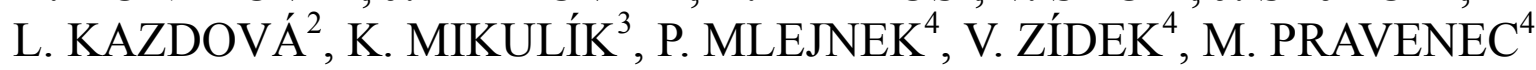 \\ ${ }^{1}$ Department of Biochemistry and Microbiology, Institute of Chemical Technology, ${ }^{2}$ Institude for \\ Clinical and Experimental Medicine, ${ }^{3}$ Institute of Microbiology, and ${ }^{4}$ Institute of Physiology, \\ Academy of Sciences of the Czech Republic, Prague, Czech Republic
}

Received June 7, 2007

Accepted June 13, 2007

\begin{abstract}
Summary
In the current study, we tested a hypothesis that CD36 fatty acid (FA) transporter might affect insulin sensitivity by indirect effects on FA composition of adipose tissue. We examined the effects of CD36 downregulation by RNA interference in 3T3-L1 adipocytes on FA transport and composition and on sensitivity to insulin action. Transfected 3T3-L1 adipocytes, without detectable CD36 protein, showed reduced neutral lipid levels and significant differences in FA composition when levels of essential FA and their metabolites were lower or could not be detected including gamma linolenic (C18:3 n6), eicosadienic (C20:2 n6), dihomo-gamma linolenic (C20:3 n6), eicosapentaenoic (EPA) (C20:5 n3), docosapentaenoic (DPA) (C22:5 n3), and docosahexaenoic (DHA) (C22:6 n3) FA. Transfected 3T3-L1 adipocytes exhibited a significantly higher $\mathrm{n} 6 / \mathrm{n} 3 \mathrm{FA}$ ratio, reduced $\Delta 5$-desaturase and higher $\Delta 9$-desaturase activities. These lipid profiles were associated with a significantly reduced insulin-stimulated glucose uptake $(4.02 \pm 0.1$ vs. $8.42 \pm 0.26$ pmol. $10^{-3}$ cells, $\mathrm{P}=0.001$ ). These findings provide evidence that $\mathrm{CD} 36$ regulates $\mathrm{FA}$ composition thereby affecting sensitivity to insulin action in 3T3-L1 adipocytes.
\end{abstract}

Key words

CD36 • 3T3-L1 adipocytes $\bullet$ RNA interference $\bullet$ Fatty acid composition $\bullet$ Insulin sensitivity

The metabolic syndrome represents a major risk for development of cardiovascular disease and type 2 diabetes. The pathogenesis of the metabolic syndrome is not fully understood, but it is widely accepted that resistance to insulin action, especially in adipose tissue, plays an important role in this syndrome (Schafrir et al. 2003, Reaven et al. 1999). The spontaneously hypertensive rat (SHR) is the most widely studied model of hypertension. Under the appropriate environmental conditions it also develops metabolic disturbances similar to those found in patients with the metabolic syndrome (Pravenec et al. 2004). A deletion mutation of $\mathrm{Cd} 36$ in the SHR was identified as an insulin resistance gene causing defective FA metabolism (Aitman et al. 1999; Pravenec et al. 2001). It has been demonstrated that $\mathrm{Cd} 36$ deletion is associated with a significantly reduced FA 
transport into adipocytes, however, the mechanisms connecting decreased FA uptake to insulin resistance in adipose tissue are not fully understood. In the current study, we analyzed the effects of CD36 on both the quantity of total lipids in adipocytes and on the FA composition in relation to insulin sensitivity. Specifically, we examined the effects of $\mathrm{Cd} 36$ downregulation by RNA interference in 3T3-L1 adipocytes on FA composition and sensitivity to insulin action.

Transfected 3T3-L1 adipocytes contained no detectable CD36 protein contrary to nontransfected controls (Fig. 1A) which confirmed the efficiency of RNA interference. The absence of CD36 was associated with lower lipid levels (Fig. 1B). Analysis of FA in control and transfected adipocytes revealed significant differences in FA composition (Table 1). Transfected 3T3-L1 adipocytes showed significantly increased levels of some shorter saturated FA (C14-C17) such as myristic (C14:0), pentadecanic (C15:0), and margaric (C17:0) and monounsaturated FA such as palmitooleic (C16:1 n7) or palmitoelaidic (C16:1 n9). However, there were no significant differences between total levels of saturated
(SFA), monounsaturated (MUFA) and polyunsaturated FA (PUFA) concentrations. There were significantly lower levels of linoleic acid (C18:2 n6) and a higher proportion of dihomo-gamma linolenic acid (C20:3 n6), and adrenic acid (C22:4 n6), whereas levels of arachidonic acid (C20:4 n6) were not different between transfected and control adipocytes. Some FA could not be detected in transfected 3T3-L1 adipocytes contrary to controls, including eicosadienic (C20:2 n6), eicosapentaenoic (EPA) (C20:5 n3), docosapentaenoic (DPA) (C22:5 n3), and docosahexaenoic (DHA) (C22:6 n3) FA. The absence of CD36 in 3T3-L1 adipocytes was associated with decreased activity of $\Delta 5$-desaturase, while the activity of $\Delta 9$-desaturase was increased and no significant differences were observed in estimated activities of $\Delta 6$-desaturase and elongase. The n6/n3 FA ratio was significantly increased in transfected 3T3-L1 adipocytes (Table 1). Transfected 3T3-L1 adipocytes exhibited significantly reduced insulin-stimulated glucose uptake when compared to control 3T3-L1 adipocytes (Fig. 1C).
A)

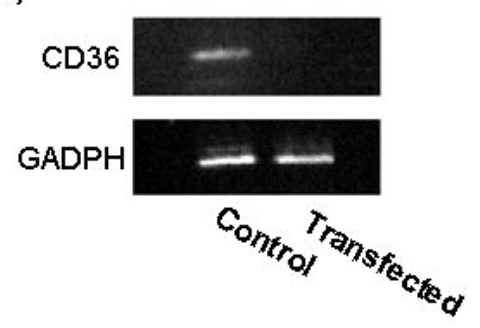

B)

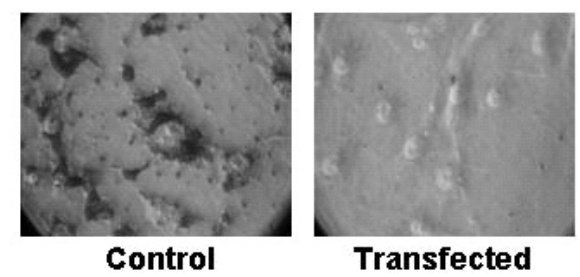

C)

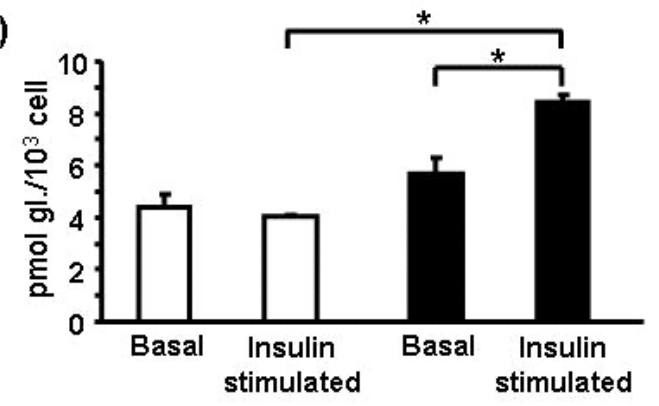

Fig. 1A. Expression of membrane protein CD36 and GAPDH control protein in 3T3-L1 adipocytes analyzed by Western blotting with specific antibody directed against CD36 and GADPH. There was no detectable CD36 protein in transfected 3T3-L1 adipocytes compared to controls. 3T3-L1 cells were transfected with a linear plasmid, prepared by cloning complementary sequence to mouse Cd36 gene within pSilencer ${ }^{\mathrm{TM}}$ 4.1-CMV (Ambion). 3T3-L1 cells were differentiated by a standard method. Western blot analysis was performed as described previously (Pravenec et al. 2001) with goat polyclonal antibody against mouse CD36 (Santa Cruz Biotechnology). B. Oil Red O staining of control and transfected differentiated 3T3-L1 adipocytes. Lipid levels were increased in 3T3-L1 control adipocytes compared to transfected cells without detectable CD36 protein. C. Basal and insulin-stimulated glucose transport in transfected 3T3-L1 adipocytes without CD36 protein (open bars) and in control cells (solid bars) was determined as previously described (Pravenec et al. 2003). Insulin-stimulated glucose transport was significantly higher in nontransfected controls. * denotes $\mathrm{P}<0.001$ 
Table 1. Fatty acid composition in transfected 3T3-L1 adipocytes without functional CD36 protein compared to controls.

\begin{tabular}{|c|c|c|c|c|}
\hline & FA & Transfected & Control & $\mathbf{P}<$ \\
\hline \multirow[t]{6}{*}{$S F A$} & C 14:0 & $2.62 \pm 0.31$ & $1.27 \pm 0.25$ & 0.05 \\
\hline & C 15:0 & $2.19 \pm 0.28$ & $0.4 \pm 0.11$ & 0.01 \\
\hline & C 16:0 & $18.43 \pm 0.68$ & $18.72 \pm 1.79$ & N.S. \\
\hline & C 17:0 & $2.13 \pm 0.25$ & $0.5 \pm 0.14$ & 0.01 \\
\hline & C18:0 & $13.81 \pm 1.07$ & $16.14 \pm 1.63$ & N.S. \\
\hline & C 22:0 & $1.59 \pm 0.08$ & $0.76 \pm 0.19$ & 0.02 \\
\hline$\Sigma S F A$ & & $40.77 \pm 2.724$ & $37.79 \pm 3.12$ & N.S. \\
\hline \multirow[t]{4}{*}{$M U F A$} & C 16: $1 \mathrm{n} 9$ & $4.26 \pm 0.35$ & $1.42 \pm 0.36$ & 0.01 \\
\hline & C $16: 1 \mathrm{n} 7$ & $3.63 \pm 0.39$ & $1.67 \pm 0.33$ & 0.02 \\
\hline & C 18:1 n9 & $26.57 \pm 0.5$ & $34.89 \pm 1.78$ & 0.01 \\
\hline & C 18:1 n7 & $7.80 \pm 0.82$ & $7.64 \pm 0.45$ & N.S. \\
\hline$\Sigma M U F A$ & & $42.26 \pm 3.94$ & $45.62 \pm 5.5$ & N.S. \\
\hline \multirow[t]{6}{*}{$P U F A-n 6$} & C 18:2 n6 & $5.33 \pm 0.49$ & $7.72 \pm 0.15$ & 0.01 \\
\hline & C 18:3 n6 & $0.13 \pm 0.02$ & $0.4 \pm 0.03$ & 0.01 \\
\hline & C 20:2 n6 & 0 & $0.15 \pm 0.04$ & N.D. \\
\hline & C $20: 3$ n6 & $3.47 \pm 0.45$ & $1.27 \pm 0.09$ & 0.01 \\
\hline & C 20:4 n6 & $3.52 \pm 0.3$ & $3.85 \pm 0.37$ & N.S. \\
\hline & C 22:4 n6 & $3.36 \pm 0.34$ & $0.6 \pm 0.2$ & 0.01 \\
\hline$\Sigma P U F A n 6$ & & $15.81 \pm 0.84$ & $13.99 \pm 1.07$ & N.S. \\
\hline \multirow[t]{5}{*}{$P U F A-n 3$} & C 18:3 n3 & $0.63 \pm 0.16$ & $1.12 \pm 0.12$ & 0.05 \\
\hline & C $20: 5$ n3 & 0 & $0.19 \pm 0.02$ & N.D. \\
\hline & C 22:5 n3 & 0 & $0.46 \pm 0.24$ & N.D. \\
\hline & C 22:6 n3 & 0 & $0.44 \pm 0.15$ & N.D. \\
\hline & others & $0.65 \pm 0.42$ & $0.45 \pm 0.31$ & N.S. \\
\hline$\Sigma P U F A-n 3$ & & $1.28 \pm 0.16$ & $2.66 \pm 0.16$ & 0.01 \\
\hline$n 6$ & & $15.81 \pm 0.835$ & $13.99 \pm 1.07$ & N.S. \\
\hline$n 3$ & & $1.28 \pm 0.157$ & $2.66 \pm 0.16$ & 0.01 \\
\hline$\Sigma P U F A$ & & $17.09 \pm 7.27$ & $16.65 \pm 5.7$ & N.S. \\
\hline$n 6 / n 3$ & & $12.35 \pm 0.71$ & $5.38 \pm 0.38$ & 0.001 \\
\hline Elongase & & $0.75 \pm 0.05$ & $0.85 \pm 0.01$ & N.S. \\
\hline$\Delta 6$ desaturase & & $0.03 \pm 0.01$ & $0.05 \pm 0.01$ & N.S. \\
\hline$\triangle 5$ desaturase & & $1.02 \pm 0.07$ & $3.29 \pm 0.35$ & 0.01 \\
\hline$\Delta 9$ desaturase & & $0.19 \pm 0.02$ & $0.1 \pm 0.02$ & 0.05 \\
\hline
\end{tabular}

Values (molar \%) are expressed as means \pm SEM. FA extracted from cytosolic fraction were analyzed by capillary gas chromatography in the Agilent 6890 instrument with flame-ionization detector and capillary colony SP $2560,100 \mathrm{~m} \times 0.25 \mathrm{~mm}$ (Supelco, USA). Individual peaks of fatty acid methylesters were identified by comparing retention times with those of authentic standards (Sigma-Aldrich, USA). The product/precursor ratios were used to calculate the activities of enzymes involved in FA metabolism: elongase (18:0/16:0), $\Delta 6-$ desaturase (18:3n6/18:2n6), $\Delta 5$-desaturase (20:4n6/20:3n6), and $\Delta 9$-desaturase (16:1n7/16:0).

Results of the current study strongly suggest that the absence of a functional CD36 protein can limit transport of long-chain FA, including essential FA. These findings provide the evidence that CD36 regulates insulin sensitivity in 3T3-L1 adipocytes by affecting FA composition and metabolism. It is therefore possible that 
a deletion mutation of the $\mathrm{Cd} 36$ gene in the SHR impairs sensitivity to insulin in adipose and muscle tissue in a similar way by interfering with FA transport and metabolism. It has been reported that the SHR exhibits impaired biogenesis of PUFA due to decreased $\Delta 5$ - and $\Delta 6$-desaturase activities when compared to Wistar-Kyoto (WKY) rats (Foucher et al. 1997). Patients with obesity and/or diabetes are characterized by increased activities of the $\Delta 9$ - and $\Delta 6$-desaturases and a decreased activity of the $\Delta 5$-desaturase with reduced proportion of linoleic (18:2 n6) and dihomo-gamma linoleic acids (20:2 n6) (Vessby et al. 2002, Warensjo et al. 2006). In addition, expression of FA handling proteins was correlated with FA composition of adipose tissue and markers of insulin resistance in humans (Gertow et al. 2006). Although it was impossible to identify causal relationships from such correlations, these findings suggested an important role of FA transport proteins in the pathogenesis of insulin resistance through their effects on FA trafficking and metabolism. Results of the current study are remarkably consistent with this hypothesis since in transfected 3T3 adipocytes, the absence of CD36 protein was associated with reduced PUFA levels, increased $\Delta 9$-desaturase, decreased $\Delta 5$-deaturase activities, and impaired insulin sensitivity. Our in vitro results thus suggest that disturbances in facilitated long-chain FA transport might represent primary defects in adipose tissue insulin sensitivity.

\section{Acknowledgements}

The authors acknowledge the support by grants 1M6837805002 from the Ministry of Education of the Czech Republic, research project AV0Z 50110509 and grants 8545-3 and 8495-3 from IGA of the Ministry of Health of the Czech Republic. M.P. is an international research scholar of the Howard Hughes Medical Institute.

\section{References}

AITMAN TJ, GLAZIER AM, WALLACE CA, COOPER LD, NORSWORTHY PJ, AL-MAJALI KM, TREMBLING PM, MANN CJ, SHOULDERS CC, GRAF D, ST LEZIN E, KURTZ TW, KŘEN V, PRAVENEC M, IBRAHIMI A, ABUMRAD NA, STANTON LW, SCOTT J: Identification of Cd36 (Fat) as an insulinresistance gene causing defective fatty acid and glucose metabolism in hypertensive rats. Nat Genet 21: 76-83, 1999.

FOUCHER C, NARCE M, NASR L, DELACHAMBRE MC, POISSON JP: Liver microsomal membrane fluidity and microsomal desaturase activities in adult spontaneously hypertensive rats. J Hypertens 15: 863-869, 1997.

GERTOW K, ROSELL M, SJOGREN P, ERIKSSON P, VESSBY B, DE FAIRE U, HAMSTEN A, HELLENIUS ML, FISHER RP: Fatty acid handling protein expression in adipose tissue, fatty acid composition of adipose tissue and serum, and markers of insulin resistance. Eur J Clin Nutr 60: 1406-1413, 2006.

PRAVENEC M, LANDA V, ZÍDEK V, MUSILOVÁ A, KŘEN V, KAZDOVÁ L, AITMAN TJ, GLAZIER AM, QI N, WANG J, ST LEZIN EM, KURTZ TW: Transgenic rescue of Cd36 improves insulin resistance and dyslipidemia in spontaneously hypertensive rats. Nat Genet 27: 156-158, 2001.

PRAVENEC M, LANDA V, ZÍDEK V, MUSILOVÁ A, KAZDOVÁ L, QI N, WANG J, ST LEZIN E, KURTZ TW: Transgenic expression of CD36 in the spontaneously hypertensive rat is associated with amelioration of metabolic disturbances but has no effect on hypertension. Physiol Res 52: 681-688, 2003.

PRAVENEC M, ZÍDEK V, LANDA V, ŠIMÁKOVÁ M, MLEJNEK P, KAZDOVÁ L, BÍLÁ V, KŘENOVÁ D, KŘEN V: Genetic analysis of "metabolic syndrome" in the spontaneously hypertensive rat. Physiol Res $\mathbf{5 3}$ (Suppl 1): S15-S22, 2004.

REAVEN GM: The pathophysiological consequences of adipose tissue insulin resistance. In: Insulin Resistance. The Metabolic Syndrome X. REAVEN GM, LAWS A (eds), Humana Press, Totowa, NJ, 1999, pp 233-246.

SHAFRIR E, RAZ I: Diabetes: mellitus or lipidus? Diabetologia 46: 433-440, 2003.

VESSBY B, GUSTAVSSON I-B, TENGBLAD S, BOBERG M, ANDERSSON A: Desaturation and elongation of fatty acids and insulin action. Ann N Y Acad Sci 967: 183-195, 2002.

WARENSJO E, OHRVALL M, VESSBY B: Fatty acid composition and estimated desaturase activities are associated with obesity and lifestyle variables in men and women. Nutr Metab Cardiovasc Dis 16: 128-136, 2006.

\section{Corresponding author}

M. Pravenec, Institute of Physiology, Czech Academy of Sciences, Vídeňská 1083, 14220 Prague 4, Czech Republic. Fax: (+420)24108 2488. E-mail: pravenec@biomed.cas.cz 


\title{
Ethanol Consumption Affects Lipoprotein Lipase Gene Expression in C57BL/6 Mice
}

\author{
E. MUDRÁKOVÁ ${ }^{1,2}$, J. KOVÁŔ $\check{R}^{1,2}$ \\ ${ }^{1}$ Institute for Clinical and Experimental Medicine, Laboratory for Atherosclerosis Research and \\ ${ }^{2}$ Center for Cardiovascular Research, Prague, Czech Republic
}

Received March 12, 2007

Accepted June 1, 2007

\begin{abstract}
Summary
The activity of lipoprotein lipase (LPL) is increased after alcohol consumption and can contribute to an increased level of HDL-cholesterol, which is considered to play a key role in the ethanol-mediated protective effect against cardiovascular disease. The increase in HDL-cholesterol concentration can be also due to an ethanol-enhanced synthesis and secretion of apolipoprotein A-I (apo A-I) from hepatocytes. Therefore, the hypothesis that ethanol consumption affects the LPL and apo A-I gene ( $L P L$ and APOA1, respectively) expression was tested in male C57BL/6 mice drinking $5 \%$ ethanol or water and fed a standard chow or high-fat (HF) diet for 4 weeks. The $L P L$ expression was determined in the heart, epididymal and dorsolumbal adipose tissues, the APOAl expression in the liver. Alcohol consumption did not affect lipid and lipoprotein concentrations in the serum. The $L P L$ expression was increased in the heart of mice given ethanol and HF diet compared to mice on chow and ethanol $(\mathrm{p}<0.001)$ and was also increased in epididymal fat in mice given ethanol and HF diet compared to mice on water and HF diet $(\mathrm{p}<0.05)$. Neither $L P L$ expression in dorsolumbal fat nor $A P O A 1$ expression in the liver were affected by ethanol consumption. Our data suggest that ethanol consumption upregulate $L P L$ expression in a tissue- and diet-dependent manner.
\end{abstract}

\section{Key words}

Apolipoprotein A-I $\bullet$ Lipoprotein lipase $\bullet$ Ethanol consumption $\bullet$ Gene expression $\bullet$ Mouse

It has been repeatedly documented that moderate alcohol consumption protects against cardiovascular disease (Langer et al. 1992, Rimm et al. 1996, Cordova et al. 2005). The substantial part of such a protective effect is due to the effect of ethanol on plasma lipoproteins, especially on the increase in HDL-cholesterol (HDL-C) concentration (Criqui et al. 1987, Suh et al. 1992, Gaziano et al. 1993). Such an increase can be explained by increased lipoprotein lipase (LPL) activity resulting in enhanced transfer of surface components (cholesterol and phospholipids) from triglyceride-rich lipoproteins (TRL) to HDL during the lipolysis of TRL-triglycerides. It has been shown that LPL activity is indeed increased after a period of alcohol consumption in humans (Schneider et al. 1985, Nishiwaki et al. 1994, Kovář and Poledne 2004). However, the exact mechanism of LPL upregulation by ethanol consumption has not been elucidated yet. Another explanation of increased HDL-C can be ethanol-stimulated secretion of apolipoprotein A-I (apo A-I) by hepatocytes (Amarasuriya et al. 1992, 
Dashti et al. 1996). Therefore, we hypothesized that alcohol consumption upregulates LPL and apo A-I at the level of gene expression. To test this hypothesis, we measured the expression of LPL and apo A-I genes ( $L P L$ and $A P O A 1$, respectively) in C57BL/6 mice drinking $5 \%$ ethanol and fed either a standard chow or high-fat (HF) diet. It is known that LPL is regulated in a tissue-specific manner. Hence, the $L P L$ expression was determined in the heart and two types of adipose tissue - epididymal and dorsolumbal fat. The expression of APOAl was measured in the liver.

Two-month-old male C57BL/6 mice $(\mathrm{n}=39)$ weighing $23.9 \pm 2.4 \mathrm{~g}$ were used in the study. The animals were randomly divided into four groups $(n=9-10)$ and housed under a 12:12 h light/dark cycle condition (lights turned on at 6:00 h) with a free access to standard laboratory (ST) chow for 1 week for acclimatization. Thereafter the animals received water and ST diet (group I), $5 \%$ ethanol (EtOH) and ST diet (group II), water and high-fat (HF) diet (chow containing $5 \%$ fat - lard) (group III), and EtOH and HF diet (group IV) for the following 4 weeks. The animals were fed ad libitum and the consumption of diets and liquids as well as weight of the animals were recorded. At the end of the alcohol and diet treatment, the animals were fasted overnight, decapitated and blood was collected for lipid and lipoprotein analysis. Samples of $\sim 30 \mathrm{mg}$ of heart $(\mathrm{H})$, epididymal (ED) and dorsolumbal (DL) adipose tissues were taken from each animal in doublets after decapitation, immediately frozen in liquid nitrogen and stored in $-80^{\circ} \mathrm{C}$ until use. The protocol of the study was approved by the Central Commission for Animal Welfare of the Czech Republic.

Serum total cholesterol (TC) and triglycerides (TG) and non-esterified fatty acids (NEFA) were measured on an automatic analyzer (COBAS MIRA+, Roche, Switzerland) by commercially available enzymatic assay kits from Roche Diagnostics and Wako, Japan (NEFA). Lipoprotein fractions (VLDL at $\mathrm{d}<1.006$ $\mathrm{g} / \mathrm{ml}, \mathrm{LDL}$ at $\mathrm{d}=1.006-1.063 \mathrm{~g} / \mathrm{ml}$ and HDL at $\mathrm{d}=$ $1.063-1.210 \mathrm{~g} / \mathrm{ml}$ ) were isolated from pooled serum of each group by sequential ultracentrifugation (Havel et al. 1955).

Tissues for RNA isolation were homogenized and total RNA isolated by NucleoSpin ${ }^{\circledR}$ RNA II kits (Macherey-Nagel, Germany). The isolated RNA (100 ng) was transcribed into cDNA using RevertAid ${ }^{\mathrm{TM}}$ First Strand cDNA Synthesis Kit (Fermentas Life Sciences) in a total volume of $20 \mu \mathrm{l}$. One microliter of cDNA was used for the subsequent real-time polymerase chain reaction (qPCR) run on the Rotor-Gene RG 3000 (Corbett Research, Australia) using the Rotor-Gene 6.0.16 software version. PCR amplifications were performed in a total volume of $25 \mu 1$, containing $1 \mu \mathrm{l}$ cDNA sample, $3 \mu 125 \mathrm{mM} \mathrm{MgCl}_{2}, 2.5 \mu 1$ Taq Buffer, $1 \mu 1$ DMSO (Sigma), $0.5 \mu 12 \mathrm{mM}$ dNTP mix, $1 \mu 110 \mathrm{x}$ concentrate in DMSO SYBER Green I (Rockland, ME, USA), $0.2 \mu 150 \mu \mathrm{M}$ both forward and reverse primer and $0.1 \mu 15 \mathrm{u} / \mu 1 \mathrm{Taq}$ DNA Polymerase (Fermentas). Each PCR amplification was performed in triplets, using the following conditions: $5 \mathrm{~min} 95{ }^{\circ} \mathrm{C}, 35$ repeats of $20 \mathrm{~s}$ $95^{\circ} \mathrm{C}, 20 \mathrm{~s} 67{ }^{\circ} \mathrm{C}(L P L)$ or $46^{\circ} \mathrm{C}(A P O A l)$ and $20 \mathrm{~s}$ $72{ }^{\circ} \mathrm{C}$, and $10 \mathrm{~min} 72{ }^{\circ} \mathrm{C}$. Mouse cyclophilin B gene $(\mathrm{CPH})$ was used as inner standard (housekeeping gene) in both kinds of reactions. The following primer sets were used: $L P L$, sense 5'-AGC CCC CAG TCG CCT TTC TCC T-3' and antisense 5'-TGC TTT GCT GGG GTT TTC TTC ATT CA-3'; APOA1, sense 5'-CGT GGC TCT GGT CTT CCT GAC-3' and antisense 5'-CAC CCA ATC TGT TTC TTT CTC C-3', and $C P H$, sense 5'-ACT ACG GGC CTG GCT GGG TGA G-3' and antisense 5'-TGC CGG AGT CGA CAA TGA TGA-3'. All primers were obtained from Generi Biotech, Czech Republic. Following PCR, melting analysis was performed. To measure the gene expression quantitatively, the external standards for each target gene ( $L P L$ and $A P O A 1)$ as well as for $C P H$ were constructed by cloning purified PCR products into pDrive Cloning Vector (QIAGEN ${ }^{\circledR}$ PCR Cloning ${ }^{\text {PLUS }}$ Kit). Ligated fragments were transformed into QIAGEN EZ Competent Cells (Qiagen). Plasmid DNA was isolated by fast alkaline lysis, its concentration detected (UV 1101, Biotech Photometer) and the concentration of $L P L, A P O A 1$ and $C P H$ calculated. Then, serial dilutions were prepared and run in $\mathrm{qPCR}$ as standard curves. Target gene: housekeeping gene ratios were compared. Results for total cholesterol, triglycerides and non-esterified fatty acids were analyzed by analysis of variance (ANOVA). When significantly different by ANOVA, the Student-Newman-Keuls (SNK) test was used (Glantz 1992). The expression of $L P L$ and APOA1 were compared using Kruskal-Wallis test followed by Dunn's test if needed (Glantz 1992).

During 4-week ethanol and diet treatment, there were no significant differences in diet consumption. However, the weight of mice fed the HF diet and $\mathrm{EtOH}$ (group IV) increased more throughout the experiment than that of mice fed the ST diet $(2.80 \pm 1.69,3.11 \pm 1.01$, $4.20 \pm 1.48$, and $5.80 \pm 1.48 \mathrm{~g}$, group I to group IV). Mice 
Table 1. Concentration of plasma lipids and lipoproteins.

\begin{tabular}{|c|c|c|c|c|c|}
\hline & $\begin{array}{c}\text { ST, W } \\
\text { (Group I) }\end{array}$ & $\begin{array}{c}\text { ST, EtOH } \\
\text { (Group II) }\end{array}$ & $\begin{array}{c}\text { HF, W } \\
\text { (Group III) }\end{array}$ & $\begin{array}{c}\text { HF, EtOH } \\
\text { (Group IV) }\end{array}$ & p \\
\hline \multicolumn{6}{|c|}{ Lipids (mmol/l) } \\
\hline$T C$ & $1.67 \pm 0.20$ & $1.65 \pm 0.26$ & $2.25 \pm 0.41 *^{\#}$ & $2.10 \pm 0.29 *^{\#}$ & $<0.001$ \\
\hline$T G$ & $0.59 \pm 0.14$ & $0.50 \pm 0.10$ & $0.55 \pm 0.10$ & $0.47 \pm 0.06$ & $\mathrm{~ns}$ \\
\hline$N E F A$ & $0.82 \pm 0.15$ & $0.76 \pm 0.15$ & $0.86 \pm 0.20$ & $0.93 \pm 0.14$ & ns \\
\hline \multicolumn{6}{|c|}{ Lipoproteins (mmol/l) } \\
\hline$V L D L-T G$ & 0.31 & 0.27 & 0.33 & 0.25 & - \\
\hline$L D L-C$ & 0.27 & 0.23 & 0.36 & 0.29 & - \\
\hline$H D L-C$ & 1.40 & 1.40 & 1.36 & 1.50 & - \\
\hline
\end{tabular}

Data for lipids are mean \pm S.D. The differences in total cholesterol (TC), triglycerides (TG) and non-esterified fatty acids (NEFA) were evaluated by ANOVA and SNK tests. Significantly different from: * group I, \# group II. Data for VLDL-triglycerides, LDL- and HDLcholesterol (LDL-C and HDL-C, respectively) were obtained after ultracentrifugation of pooled serum samples. EtOH - ethanol, HF - high-fat diet, ST - standard laboratory diet, W - water.

Table 2. Expression of $\angle P L$ in heart, epididymal and dorsolumbal adipose tissue and expression of $A P O A 1$ in the liver.

\begin{tabular}{|c|c|c|c|c|c|}
\hline & $\begin{array}{c}\text { ST, W } \\
\text { (Group I) }\end{array}$ & $\begin{array}{c}\text { ST, EtOH } \\
\text { (Group II) }\end{array}$ & $\begin{array}{c}\text { HF, W } \\
\text { (Group III) }\end{array}$ & $\begin{array}{c}\text { HF, EtOH } \\
\text { (Group IV) }\end{array}$ & p \\
\hline \multicolumn{6}{|c|}{ LPL:CPH ratio } \\
\hline$L P L-H$ & $22.3(18.8 ; 39.3)$ & $13.1(11.0 ; 21.8)$ & $44.0(29.2 ; 58.0)$ & $175.9(74.8 ; 232.0)^{\#}$ & $<0.001$ \\
\hline$L P L-E D$ & $149.9(100.7 ; 215.5)$ & $94.8(43.0 ; 118.7)$ & $55.6(51.0 ; 167.6)$ & $1163.0(197.3 ; 1794.7)^{\#-1}$ & $<0.05$ \\
\hline$L P L-D L$ & $3.4(0.6 ; 13.3)$ & $4.3(0.4 ; 11.4)$ & $0.3(0.3 ; 7.8)$ & $9.2(1.0 ; 13.1)$ & ns \\
\hline \multicolumn{6}{|c|}{ APOA1:CPH ratio } \\
\hline $\begin{array}{l}A P O A-I \\
\left(x 10^{3}\right)\end{array}$ & $327.0(217.3 ; 658.4)$ & $625.2(137.0 ; 713.0)$ & $\begin{array}{c}533.0(107.5 \\
700.0)\end{array}$ & $297.0(130.7 ; 338.3)$ & ns \\
\hline
\end{tabular}

Data are median (1st quartile; 3rd quartile). The differences in $L P L$ expression in heart ( $L P L-H)$, epididymal $(\angle P L-E D)$ and dorsolumbal $(L P L-D L)$ adipose tissues were evaluated by Kruskal-Wallis statistics and if needed by Dunn's test. Significantly different from: ${ }^{\#}$ group II, ${ }^{+}$group III. EtOH - ethanol, HF - high-fat diet, ST - standard chow, W - water.

fed the HF diet with EtOH (group IV) had significantly lower liquid consumption than all other groups $(5.94 \pm 0.69, \quad 5.81 \pm 1.38, \quad 6.01 \pm 0.34$ and $4.90 \pm 1.12$ $\mathrm{ml}$ /day/animal). There was no difference in total cholesterol concentration between groups of animals fed the same diet, but concentrations of total cholesterol in both groups fed the HF diet were higher than in groups on ST diet $(\mathrm{p}<0.001)$ (Table 1). There were no differences in TG and NEFA concentrations between the groups. The data for triglycerides and cholesterol concentrations in VLDL, LDL and HDL (Table 1) did not show any pronounced differences; however, due to use of pooled serum samples, the data cannot be evaluated with respect to statistical significance. The effect of ethanol consumption together with HF diet on the $L P L$ expression was studied in the heart ( $L P L-H)$, epididymal ( $L P L-E D)$ and dorsolumbal $(L P L-D L)$ adipose tissue, and on the $A P O A 1$ expression in the liver (Table 2). The $L P L-H$ expression was significantly higher in mice fed the HF diet and EtOH than in mice fed the ST diet and EtOH $(\mathrm{p}<0.001)$. The LPL-ED expression was significantly higher in mice fed the HF diet and EtOH than in mice fed ST diet with EtOH and than in mice fed HF diet with water $(\mathrm{p}<0.05)$. There was no effect of alcohol and HF diet on the $L P L-D L$ expression and on the APOA1 expression in the liver.

We demonstrated that $L P L$ expression is upregulated in the heart and epididymal fat (but not in 
dorsolumbal fat) of C57BL/6 mice given $5 \%$ ethanol and high-fat diet. No effect of ethanol consumption can be observed when the mice are fed only the standard laboratory diet. The APOA1 expression was not affected either by ethanol consumption or HF diet. Our findings are in rather good agreement with observations in humans that LPL activity is increased after a period of moderate alcohol consumption (Schneider et al. 1985, Nishiwaki et al. 1994, Kováŕ and Poledne 2004). It can be speculated that such an increase in $L P L$ expression represents a metabolic response to the higher supply of TRL to tissues due to an increased dietary fat intake and increased VLDL production from the liver because of the lipogenic effect of ethanol (Sane et al. 1984, Baraona and Lieber 1998). Increased LPL activity should then attenuate the response of triglyceridemia to alcohol intake and may explain why there are no differences in TG concentration between groups. At the moment we have no data available to suggest the mechanism of LPL upregulation - it can be speculated that activation of gene expression through PPAR-alpha due to increased fatty acid supply may be involved (Jump et al. 2005). However, our findings of upregulation of $L P L$ expression by alcohol consumption need to be confirmed in independent experiments. Rather surprisingly, we did not observe any effect of ethanol on cholesterol and HDL-C concentration in the serum. Increased level of HDL-C is considered to be the main part of ethanol-mediated cardiovascularprotective effect in humans (Gaziano et al. 1993, Chung et al. 2003, Hansen et al. 2005, Naissides et al. 2006). On the contrary, in mice, alcohol consumption was found to be associated with both an increase (Bentzon et al. 2001) and a decrease in HDL-C level (Emeson et al. 1995, 2000, Munday et al. 1999, Escola-Gil et al. 2004). In the light of these facts, we can speculate that in our study, in which no cholesterol was added to the HF-diet, the impact on HDL-C could be minimalized. It was shown that apo A-I synthesis and secretion from hepatocytes is increased when HepG2 cells are incubated with ethanol (Amarasuriya et al. 1992, Dashti et al. 1996). Our data do not support such findings; however, there could be interspecies differences in regulation of apo A-I synthesis as can also be seen from inconsistent effects of alcohol consumption on HDL-C concentration in mice.

In conclusion, our results demonstrate that moderate ethanol consumption (together with an increased intake of fat) results in upregulation of $L P L$ expression in a tissue-specific manner in C57BL/6 mice.

\section{Acknowledgements}

This work was supported by grant \# NR/7847-3 from IGA MH CR.

\section{References}

AMARASURIYA RN, GUPTA AK, CIVEN M, HORNG YC, MAEDA T, KASHYAP ML: Ethanol stimulates apolipoprotein A-I secretion by human hepatocytes: implications for a mechanism for atherosclerosis protection. Metabolism 41: 827-832, 1992.

BARAONA E, LIEBER CS: Alcohol and lipids. Recent Dev Alcohol 14: 97-134, 1998.

BENTZON JF, SKOVENBORG E, HANSEN C, MOLLER J, DE GAULEJAC NS, PROCH J, FALK E: Red wine does not reduce mature atherosclerosis in apolipoprotein E-deficient mice. Circulation 103: 1681-1687, 2001.

CHUNG BH, DORAN S, LIANG P, OSTERLUND L, CHO BH, OSTER RA, DARNELL B, FRANKLIN F: Alcoholmediated enhancement of postprandial lipemia: a contributing factor to an increase in plasma HDL and a decrease in risk of cardiovascular disease. Am J Clin Nutr 78: 391-399, 2003.

CORDOVA AC, JACKSON LS, BERKE-SCHLESSEL DW, SUMPIO BE: The cardiovascular protective effect of red wine. J Am Coll Surg 200: 428-439, 2005.

CRIQUI MH, COWAN LD, TYROLER HA, BANGDIWALA S, HEISS G, WALLACE RB, COHN R: Lipoproteins as mediators for the effects of alcohol consumption and cigarette smoking on cardiovascular mortality: results form the Lipid Research Clinics Follow-up Study. Am J Epidemiol 126: 629-637, 1987.

DASHTI N, FRANKLIN FA, ABRAHAMSON DR: Effect of ethanol on the synthesis and secretion of apoA-I- and apoB-containing lipoproteins in HepG2 cells. J Lipid Res 37: 810-824, 1996.

EMESON EE, MANAVES V, SINGER T, TABESH M: Chronic alcohol feeding inhibits atherogenesis in C57BL/6 hyperlipidemic mice. Am J Pathol 147: 1749-1758, 1995. 
EMESON EE, MANAVES V, EMESON BS, CHEN L, JOVANOVIC I: Alcohol inhibits the progression as well as the initiation of atherosclerotic lesions in C57Bl/6 hyperlipidemic mice. Alcohol Clin Exp Res 24: 1456-1466, 2000.

ESCOLA-GIL JC, CALPE-BERDIEL L, RIBAS V, BLANCO-VACA F: Moderate beer consumption does not change early or mature atherosclerosis in mice. Nutr J 3: 1, 2004.

GAZIANO JM, BURING JE, BRESLOW JL, GOLDHABER SZ, ROSNER B, VANDENBURGH M, WILLETT W, HENNEKENS CH: Moderate alcohol intake, increased levels of high-density lipoprotein and its subfractions, and decreased risk of myocardial infarction. N Engl J Med 329: 1829-1834, 1993.

GLANTZ SA: Primer of Biostatistics. Third edition. McGraw-Hill, Inc, New York, 1992.

HANSEN AS, MARCKMANN P, DRAGSTED LO, FINNE NIELSEN IL, NIELSEN SE, GRONBAEK M: Effect of red wine and red grape extract on blood lipids, haemostatic factors, and other risk factors for cardiovascular disease. Eur J Clin Nutr 59: 449-455, 2005.

HAVEL RJ, EDER HA, BRAGDON JH: The distribution and chemical composition of ultracentrifugally separated lipoproteins in human serum. J Clin Invest 34: 1345-1353, 1955.

JUMP DB, BOTOLIN D, WANG Y, XU J, CHRISTIAN B, DEMEURE O: Fatty acid regulation of hepatic gene transcription. J Nutr 135: 2503-2506, 2005.

KOVÁŘ J, POLEDNE R: Influence of moderate alcohol consumption on lipoprotein metabolism (in Czech). Cor Vasa 46: 110-114, 2004.

LANGER RD, CRIQUI MH, REED DM: Lipoproteins and blood pressure as biological pathways for effect of moderate alcohol consumption on coronary heart disease. Circulation 85: 910-915, 1992.

MUNDAY JS, THOMPSON KG, JAMES KA, MANKTELOW BW: The effect of moderate alcohol consumption as either red or white wine in the C57BL/6 mouse atherosclerosis model. Coron Artery Dis 10: 97-102, 1999.

NAISSIDES M, MAMO JC, JAMES AP, PAL S: The effect of chronic consumption of red wine on cardiovascular disease risk factors in postmenopausal women. Atherosclerosis 185: 438-445, 2006.

NISHIWAKI M, ISHIKAWA T, ITO T, SHIGE H, TOMIYASU K, NAKAJIMA K, KONDO K, HASHIMOTO H, SAITOH K, MANABE M, et al.: Effects of alcohol on lipoprotein lipase, hepatic lipase, cholesteryl ester transfer protein, and lecithin:cholesterol acyltransferase in high-density lipoprotein cholesterol elevation. Atherosclerosis 111: 99-109, 1994.

RIMM EB, KLATSKY A, GROBBEE D, STAMPFER MJ: Review of moderate alcohol consumption and reduced risk of coronary heart disease: is the effect due to beer, wine, or spirits. BMJ 312: 731-736, 1996.

SANE T, NIKKILA EA, TASKINEN MR, VALIMAKI M, YLIKAHRI R: Accelerated turnover of very low density lipoprotein triglycerides in chronic alcohol users. A possible mechanism for the up-regulation of high density lipoprotein by ethanol. Atherosclerosis 53: 185-193, 1984.

SCHNEIDER J, LIESENFELD A, MORDASINI R, SCHUBOTZ R, ZOFEL P, KUBEL F, VANDRE-PLOZZITZKA C, KAFFARNIK H: Lipoprotein fractions, lipoprotein lipase and hepatic triglyceride lipase during short-term and long-term uptake of ethanol in healthy subjects. Atherosclerosis 57: 281-291, 1985.

SUH I, SHATEN BJ, CUTLER JA, KULLER LH: Alcohol use and mortality from coronary heart disease: the role of high-density lipoprotein cholesterol. The Multiple Risk Factor Intervention Trial Research Group. Ann Intern Med 116: 881-887, 1992.

\section{Corresponding author}

Jan Kováŕ, Institute for Clinical and Experimental Medicine, Laboratory for Atherosclerosis Research, Vídeňská 1958/9 14021 Prague 4, Czech Republic. E-mail: jan.kovar@medicon.cz 